\title{
Analysis of Hungarian sport horse show jumping results using different transformations and models
}

\author{
JÁNOS POSTA, SÁNDOR MIHÓK, SZILÁRD MÁRKUS and ISTVÁN KOMLÓSI \\ Institute for Animal Science, Centre of Agricultural Sciences and Engineering, University of Debrecen, Hungary
}

\begin{abstract}
The aim of this paper is to estimate heritabilities and to compare data transformation methods and models for Hungarian Sporthorse show jumping results. The analysis is based on data collected between 1996 and 2005. The linear animal model included fixed effects of gender, breeder, rider, age, and start (coded as year of competition, type of competition and height of obstacle). Square root, cubic and fourth roots, Blom score and cotangent transformed ranks were used as measurements of performance. Difference the height of the obstacle and fault points, height of the obstacle and height of the obstacle and fault point were also used as performance traits.

Variance and covariance components were estimated with VCE-5 software package. Model fit was evaluated by log-likelihood values and Akaike's information criterion (AIC). Heritability was low for each performance trait and each model. The poorest goodnessof-fit model was the difference between height of the obstacle and fault points, whereas the best fitting genetic model based on AIC was from using the cotangent transformation.
\end{abstract}

Keywords: show jumping, heritability, sporthorse, Hungary

\section{Zusammenfassung}

\section{Analyse der Ergebnisse von ungarischen Springreitturnieren unter Nutzung unterschiedlicher Transformationen und Modelle}

Ziel der Untersuchungen sind Heritabilitätsschätzungen von Ergebnissen ungarischer Sportpferdespringen sowie ein Vergleich dieser mittels Transformation von Daten und Modellen. Die Analyse basiert auf Daten, welche zwischen 1996 und 2005 erfasst wurden. Das lineare Tiermodell schließt die fixen Effekte Geschlecht, Züchter, Reiter, Alter und Startjahr (verschlüsselt als Wettbewerbsjahr, Turniertyp und Höhe der Hindernisse) ein. Neben der Hindernishöhe und der Anzahl an Fehlerpunkten wurde auch die Differenz zwischen der Hindernishöhe und den Fehlerpunkten als Leistungsmerkmale gewertet. Die Schätzung der Varianz- und Kovarianzkomponenten erfolgte mit dem VCE-5 Softwarepaket. Die Modellgüte wurde mittels Log-Likelihood und Akaike-Kriterium (AIC) bewertet. Die Heritabilität sowohl für die einzelnen Merkmale als auch bei den einzelnen genutzten Modellen war niedrig. Die geringste Modellgüte ergab sich für die Differenz der Hindernishöhe zu den Fehlerpunkten während die beste Anpassung der genetischen Modelle basierend auf AIC bei Anwendung der kotangenten Transformation festgestellt wurde.

Schlüsselwörter: Springreitturnier, Heritabilität, Sportpferd, Ungarn 


\section{Introduction}

Different methods have been utilized for the evaluation of performance events in sport horses. KOENEN (2002) reported about testing and genetic evaluation of sport horses from an international perspective. The evaluation of such results is difficult because performance frequently is evaluated subjectively, may be a function of a number of other traits and may not be normally distributed. In youngest time the influence of different effects to racing traits was investigated and genetic parameters of these traits was estimated by several authors (ROEHE et al. 2001, DIETL et al. 2005, EKIZ et al. 2005, POSTA et al. 2007). As VON LENGERKEN and SCHWARK (2002) concluded, jumping performance has to be considered as a complex selection trait in riding horse breeding. Log (TAVERNIER 1988) and square root (TAVERNIER 1990) transformations have been utilized in evaluations based on total earnings. Because earnings might also be related to the difficulty and prestige of a sport event, breeding value estimation is based on mathematical transformations of earnings ranks in some countries. The rankings of horses were transformed to create a normally distributed variable using the Blom score for sport horses for Irish (FORAN et al. 1995) and Belgian Sporthorse (JANSSENS et al. 1997) populations. JAITNER et al. (2005) used sales prices from auctions as a performance trait for evaluation. There is a substantial German literature on genetic parameters of various performance traits of the horse (BUGISLAUS et al. 2004).

There were some studies for breeding value estimation in Hungary also. BODÓ (1976) reported heritability of racing performance, and HECKER (1980) evaluated sires based upon scores in show jumping events of their offspring. The OMMI (National Institute for Agricultural Quality Control) published breeding values of sires based on the racing results of their offspring (NÉMETH 1993). BOKOR et al. (2006) estimated the heritability of a combination of earnings and ranking within the Hungarian Thoroughbred population.

The overall objective of the present work was to estimate heritabilities of show jumping results of Hungarian Sporthorses when records were subjected to a variety of statistical transformations. Results may allow enhancement of breeding value estimation procedures.

\section{Material and methods}

The data used for analysis were obtained from the Hungarian Equestrian Federation and consisted of records of faults, times, final placing and points for each horse in every show jumping competition that took place during the period 1996 through 2005 in Hungary. Records of a horse were taken into account only if its two or more generation pedigree was documented in the Hungarian Sporthorse Studbook. After filtering, 22860 records were left for the analysis.

Rankings of sport races are not normally distributed but approximate an exponential distribution as illustrated in Figure 1a. Consequently, so ranking should be used for breeding value estimation only after an appropriate mathematical transformation. 


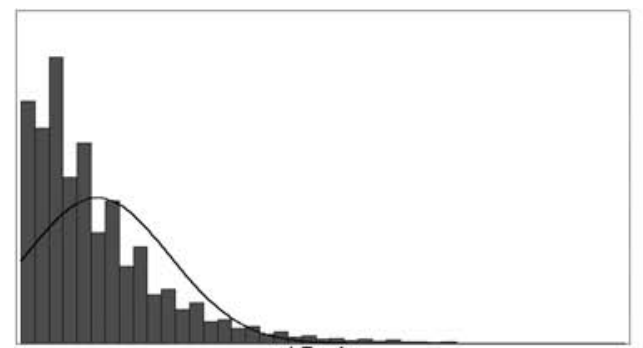

a.) Ranks

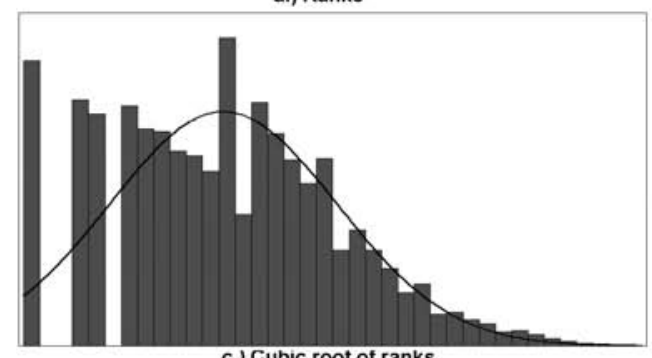

c.) Cubic root of ranks

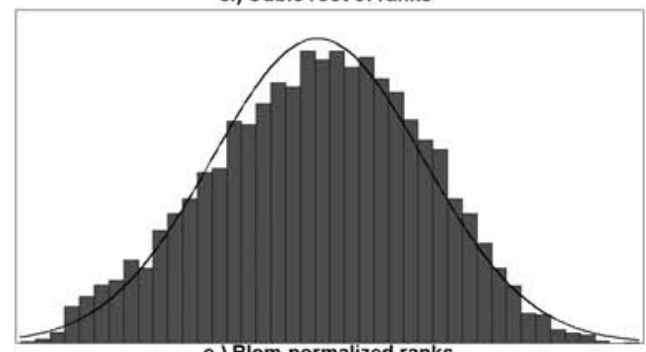

e.) Blom-normalized ranks

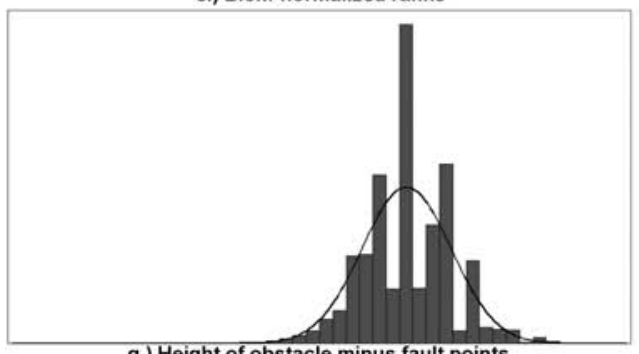

g.) Height of obstacle minus fault points

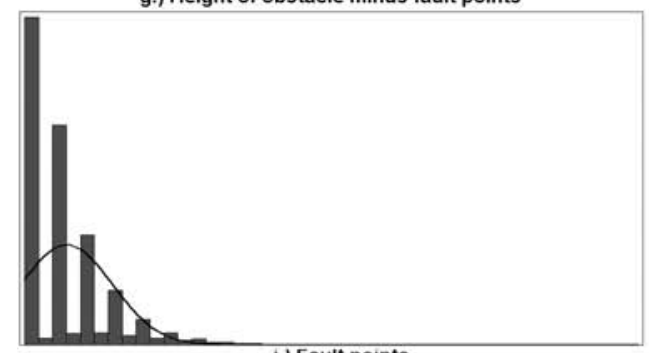

i.) Fault points

Figure 1a-i

Distribution of different measurement variables Distribution der verschiedenen gemessenen Variablen

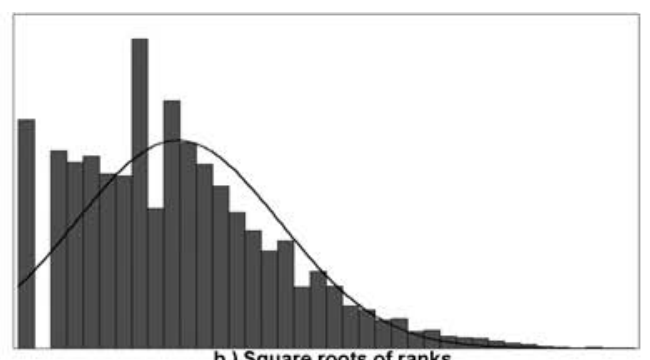

b.) Square roots of ranks

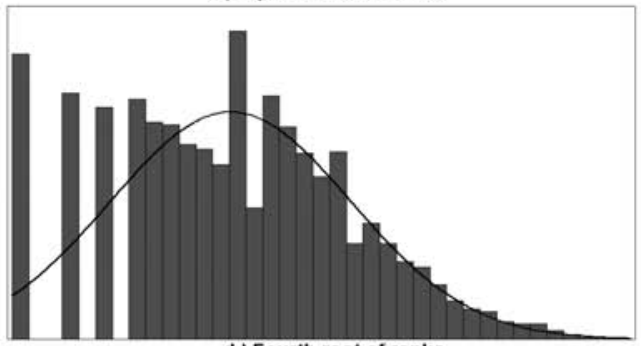

d.) Fourth root of ranks

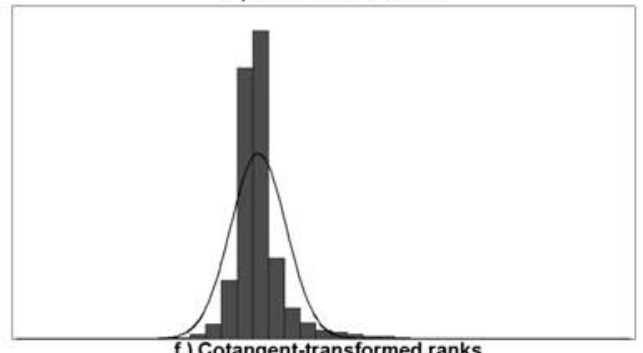

f.) Cotangent-transformed ranks

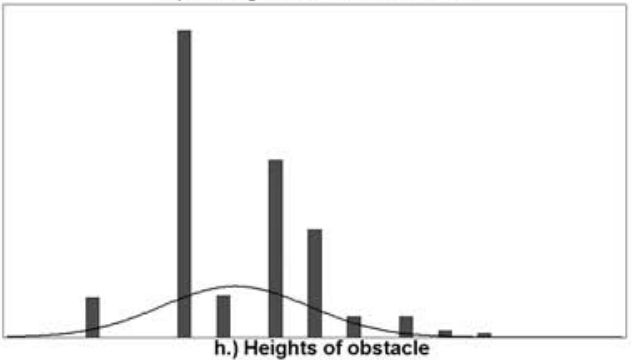




\section{Model selection}

For the evaluation of show jumping, several scores were created using different criteria and transformations and analyzed those scores with different models. Square root (1st measure), cubic root (2nd measure) and fourth root (3rd measure) can be considered as normally distributed scales (TAVERNIER 1990) and may therefore be appropriate for evaluation. As a 4th measure, we used normalized ranks from the Blom method, as described by FORAN et al. (1995) in the Irish Sporthorse population. With this method, higher ranking individuals in a competition receive positive scores, average performers receive a score of zero and the horses with poor performance ranked at the bottom of the competition receive negative scores. Scores varied in the range of -2.535 and 2.359 . Further models were investigated. In the 5th measure, the cotangent function was used to transform ranking. After the transformation of rankings, this scale had higher deviations than from the Blom method, which may accentuate performance differences among horses.

In addition to scales based on rankings, we used other measurements to evaluate performance. The height of the obstacle was used to define these further scales. The 6th measure was defined as the difference between the height of the obstacle and the number of fault points. Comparison of the performance of horses might be easier with this scale. Our 7th measure was the height of the obstacle. In the case of this scale, fault point was in the model as a random effect. Finally, in the 8th measure, height of the obstacle and fault point were each used as traits in the model. Distributions of transformed rankings and further scales are shown in Figure 1b-1i.

Each case was evaluated with two models in which the level of significance for each fixed effect was determined using SAS PROC GLM (SAS INSTITUTE 1999). In the first model, gender, breeder, rider, age and start were taken into account as fixed effects, while permanent environment effect was taken into account as a random effect. In the second model, start was considered as a random effect because it had 4000 levels.

\section{Goodness-of-fit of the models}

The goodness-of-fit of these models was assessed by using the log-likelihood value and Akaike's information criterion (AIC) (AKAIKE 1973). AIC was calculated as follows:

$$
A I C=-2 \cdot \log (\text { maximum likelihood })+2 \cdot \log (\text { number of model parameters })
$$

The model with the highest log-likelihood value and the lowest AIC was considered as the best fitting model for show jumping performance traits.

\section{Estimation of genetic parameters}

Variance components and standard errors were estimated with an animal model and a repeatability animal model using the REML with VCE-5 (KOVAC and GROENEVELD 2003) software package. 


\section{Results}

\section{Goodness-of-fit of the models}

Log-likelihood values and the AIC for different models are presented in Table 1.

Log-likelihood values did not converge for the seventh and eighth measures, so these models were the most poorly fitted. A small log-likelihood value was found for the 6th measure; whereas higher log-likelihood values were found for the 4th and 5th measures. Similar to results from log-likelihood values, AIC was the lowest in the case of the 6th measure. The fourth and the 5 th measures had the highest AIC values. These results were equally valid when start was considered a fixed or as a random effect in the model.

\section{Table 1}

Log-likelihood values and Akaike's information criterion (AIC) values using different models Genutzte Werte für Log-Likelihood und Akaike-Informationskriterien (AIC)

\begin{tabular}{lccc}
\hline Measures & Log likelihood & AIC & $N$ of model parameters \\
\hline Start as fixed effect & & & \\
1st measure & 20385.9 & -27322 & 6725 \\
2nd measure & 20753.4 & -28057 & 6725 \\
3rd measure & 21013.9 & -28578 & 6725 \\
4th measure & 28283.5 & -43261 & 6653 \\
5th measure & 29636.7 & -45967 & 6653 \\
6th measure & 12799.9 & -12150 & 6725 \\
7th measure & $-\infty$ & - & 6896 \\
8th measure & $-\infty$ & - & 13450 \\
Start as random effect & & & \\
1st measure & 21665.8 & -29882 & 6725 \\
2nd measure & 22258.8 & -31068 & 6725 \\
3rd measure & 22618.7 & -31787 & 6725 \\
4th measure & 27770.8 & -42236 & 6653 \\
5th measure & 28484.2 & -43662 & 6653 \\
6th measure & 14045.8 & -14642 & 6725 \\
7th measure & $-\infty$ & - & 6896 \\
8th measure & $-\infty$ & - & 13450 \\
\hline
\end{tabular}

\section{Estimation of genetic parameters}

Heritabilities estimated with an animal model were in the range of 0.10 to 0.25 (Table 2): whereas estimated heritabilities from the repeatability animal model were under 0.10 for each trait. Repeatabilities tended to be higher when start was considered a random rather than a fixed effect.

\section{Discussion}

\section{Goodness-of-fit of the models}

Using Akaike's information criterion (AIC) random regression models were evaluated by BUGISLAUS et al. (2006).

As shown in Table 1, our 5th measure (cotangent transformation) with start as a fixed effect fitted best to show jumping competition results. Using this model, genetic value of 
the Hungarian Sporthorse population could be relatively best estimated. Fixed effects of gender, breeder, rider, age and start, and the random permanent environmental effect should be taken into account during breeding value estimation.

\section{Estimation of genetic parameters}

Heritabilities estimated with an animal model were similar to those of HUIZINGA and van der MEIJ (1989) on Dutch Warmblood horses $\left(h^{2}=0.20\right)$. Heritabilities based on rankings were similar to those of BRUNS (1981) (between 0.14 and 0.20). WALLIN et al. (2003) reported $h^{2}=0.27$ based on rankings for Swedish Warmblood. This value was higher than the present estimations for Hungarian Sporthorses.

Heritabilities estimated with a repeatability animal model were similar to those of JANSSENS et al. (1997) (between 0.02 and 0.09) and FORAN et al. (1995) ( $\left.h^{2}=0.08\right)$. Heritability was estimated on Blom score for both of those studies.

Heritabilities estimated with an animal model were higher than those estimated with a repeatability animal model. The main reason of this effect is that in the repeatability animal model permanent environmental effect is taken into account.

Repeatabilities were higher in results than in FORAN et al. (1995), in which start was considered a fixed effect but a little smaller when start was considered random.

Table 2

Heritabilities and repeatabilities of the measurements estimated with different models (standard errors within brackets)

Heritabilität und Wiederholbarkeit der Messwerte geschätzt mit unterschiedlichen Modellen (Standardfehler in Klammern)

\begin{tabular}{lccc}
\hline Measures & $\begin{array}{c}\text { Animal model } \\
\text { Heritability }\end{array}$ & $\begin{array}{c}\text { Repeatability animal model } \\
\text { Reritability }\end{array}$ & Repeatability \\
\hline Start as fixed effect & & & \\
1st measure & $0.251(0.014)$ & $0.036(0.033)$ & 0.218 \\
2nd measure & $0.250(0.014)$ & $0.037(0.034)$ & 0.217 \\
3rd measure & $0.248(0.014)$ & $0.037(0.032)$ & 0.215 \\
4th measure & $0.273(0.015)$ & $0.073(0.037)$ & 0.241 \\
5th measure & $0.180(0.012)$ & $0.048(0.029)$ & 0.160 \\
6th measure & $0.220(0.015)$ & $0.020(0.028)$ & 0.191 \\
7th measure & - & - & - \\
8th measure & - & - & - \\
Start as random effect & & $0.050(0.025)$ & 0.137 \\
1st measure & $0.158(0.010)$ & $0.052(0.025)$ & 0.136 \\
2nd measure & $0.155(0.010)$ & $0.052(0.023)$ & 0.134 \\
3rd measure & $0.153(0.010)$ & $0.053(0.021)$ & 0.149 \\
4th measure & $0.169(0.011)$ & $0.045(0.020)$ & 0.097 \\
5th measure & $0.107(0.009)$ & $0.020(0.022)$ & 0.183 \\
6th measure & $0.217(0.013)$ & - & - \\
7th measure & - & - & - \\
8th measure & - & & \\
\hline
\end{tabular}




\section{Acknowledgements}

This work was made possible by the financial support of the »4/057/2004 NKFP« research project in a close cooperation with The Association of Hungarian Horse Breeders and Horse Organization and The Association of Hungarian Sporthorse Breeders (MSLT). The Association of Hungarian Sporthorse Breeders, and especially Zoltán Prutkay, are gratefully acknowledged for providing the data set for the study. The authors express great appreciation to Dr. William D. Hohenboken for his helpful comments on the manuscript.

\section{References}

Akaike $\mathrm{H}$ (1973) Information theory and an extension of the maximum likelihood principle. In: Petrov $\mathrm{BN}$, Csaki F (eds) Proceedings of the 2nd International Symposium on Information Theory Akademiai Kiado Budapest Hungary, 267-81

Bodó I (1976) Heritability of performance in horse breeding. Candidate dissertation, MTA Budapest [in Hungarian]

Bokor Á, Stefler J, Nagy I (2006) Genetic parameters of racing merit of Thoroughbred horses in Hungary Acta Agraria Kaposváriensis 10, 153-7

Bruns E (1981) Estimation of the breeding value of stallions from the tournament performance of their offspring, Livest Prod Sci 8, 465-73

Bugislaus A-E, Roehe R, Uphaus $H$, Kalm E (2004) Development of genetic models for estimation of racing performances in German thoroughbreds. Arch Tierz 47, 505-16

Bugislaus A-E, Roehe R, Willms F, Kalm E (2006) The use of random regression model to account for change in racing speed of German trotters with increasing age. J Anim Breed Genet 123, 239-46

Dietl G, Hoffmann S, Reinsch N (2005) Impact of trainer and judges in the mare performance test of Warmblood horses. Arch Tierz 48, 113-20

Ekiz B, Kocak Ö, Yilmaz A (2005) Phenotypic and genetic parameter estimates for racing traits of Thoroughbred horses in Turkey. Arch Tierz 48, 121-9

Foran MK, Reilly MP, Kelleher DL, Langan KW, Brophy PO (1995) Genetic evaluation of show jumping horses in Ireland using Ranks in competition. 46th Annual Meeting of the EAAP, Prague, Czech Republic

Hecker W (1980) Evaluation of sires in sport disciplines 1980/2, 12-7 [in Hungarian]

Huizinga HA, van der Meij GJW (1989) Estimated Parameters of Performance in Jumping and Dressage Competition of the Dutch Warmblood Horse. Livest Prod Sci 21, 333-45

Jaitner J, Reinhardt F, Christmann L (2005) Regional genetic evaluation, including the auction horses. 4. Pferde-Workshop Uelzen 22.-23.02.2005, 37-40 [in German]

Janssens S, Geysen D, Vandepitte W (1997) Genetic parameters for show jumping in Belgian sporthorses, 48th Annual Meeting of the EAAP, Vienna, Austria

Koenen ECP (2002) Testing and genetic evaluation of sport horses from an international perspective. Arch Tierz 45 SI, 38-44 [in German]

Kovac M, Groeneveld E (2003) VCE-5 User's Guide and Reference Manual Version 5.1. Inst Anim Sci Fed Agricult Res Center (FAL), Neustadt, Germany

Németh CS (1993) Results of horse breeding 1992. Mezőgazdasági Minősítő Intézet Kiadványa [in Hungarian]

Posta J, Komlosi I, Mihok S (2007) Principal component analysis of performance test traits in Hungarian Sporthorse mares. Arch Tierz 50, 125-35

Roehe R, Savas T, Brka M, Willms F, Kalm E (2001) Multiple-trait genetic analysis of racing performances of German trotters with disentanglement of genetic and driver effects. Arch Tierz 44, 579-87

SAS (1999) SAS/STAT Software Release 8.2 Cary NC, USA

Tavernier A (1988) Advantages of BLUP Animal Model for Breeding Value Estimation in Horses. Livest Prod Sci 20, 149-60

Tavernier A (1990) Estimation of breeding value of jumping horses from their ranks. Livest Prod Sci 26, $277-90$ 
Von Lengerken G, Schwark H-J (2002) Type and performance in horse breeding - allrounder or specialists. Arch Tierz $45 \mathrm{SI}, 68-79$ [in German]

Wallin L, Strandberg E, Philipsson J (2003) Genetic correlations between field test results of Swedish Warmblood Riding Horses as 4-year-olds and lifetime performance results in dressage and show jumping. Livest Prod Sci 82, 61-71

Received 4 July 2007, accepted 20 June 2009.

Corresponding author:

JÁNOS POSTA

email: postaj@agr.unideb.hu

Institute for Animal Science, Centre of Agricultural Sciences and Engineering, University of Debrecen, Böszörményi str. 138, 4032 Debrecen, Hungary 